\title{
Identification of pseudouridine methyltransferase in Escherichia coli
}

\author{
RYA ERO, ${ }^{1}$ LAURI PEIL, ${ }^{2}$ AIVAR LIIV, ${ }^{1}$ and JAANUS REMME ${ }^{1}$ \\ ${ }^{1}$ Institute of Molecular and Cell Biology, University of Tartu, Tartu, Estonia \\ ${ }^{2}$ Institute of Technology, University of Tartu, Tartu, Estonia
}

\begin{abstract}
In ribosomal RNA, modified nucleosides are found in functionally important regions, but their function is obscure. Stem-loop 69 of Escherichia coli 23S rRNA contains three modified nucleosides: pseudouridines at positions 1911 and 1917, and N3 methylpseudouridine $\left(\mathrm{m}^{3} \Psi\right)$ at position 1915 . The gene for pseudouridine methyltransferase was previously not known. We identified $E$. coli protein YbeA as the methyltransferase methylating $\Psi 1915$ in $23 S$ rRNA. The $E$. coli ybeA gene deletion strain lacks the N3 methylation at position 1915 of 23S rRNA as revealed by primer extension and nucleoside analysis by HPLC. Methylation at position 1915 is restored in the $y b e A$ deletion strain when recombinant YbeA protein is expressed from a plasmid. In addition, we show that purified YbeA protein is able to methylate pseudouridine in vitro using $70 S$ ribosomes but not $50 S$ subunits from the $y b e A$ deletion strain as substrate. Pseudouridine is the preferred substrate as revealed by the inability of YbeA to methylate uridine at position 1915. This shows that $\mathrm{YbeA}$ is acting at the final stage during ribosome assembly, probably during translation initiation. Hereby, we propose to rename the YbeA protein to $\mathrm{RImH}$ according to uniform nomenclature of RNA methyltransferases. RImH belongs to the SPOUT superfamily of methyltransferases. RImH was found to be well conserved in bacteria, and the gene is present in plant and in several archaeal genomes. $\mathrm{RImH}$ is the first pseudouridine specific methyltransferase identified so far and is likely to be the only one existing in bacteria, as $\mathbf{m}^{3} \Psi 1915$ is the only methylated pseudouridine in bacteria described to date.
\end{abstract}

Keywords: post-transcriptional modifications; ribosome; methyltransferase; ybeA; RImH; pseudouridine; $23 \mathrm{~S}$ rRNA

\section{INTRODUCTION}

The physiological importance of post-transcriptional modifications in rRNA is largely enigmatic. Although a ribosome lacking post-transcriptional modifications is able to synthesize peptides in vitro (Krzyzosiak et al. 1987; Cunningham et al. 1991; Green and Noller 1999; Khaitovich et al. 1999), the conservation and clustering of modified nucleosides in functionally important regions of the ribosome suggest that they might be important for efficient translation, rRNA folding, ribosome assembly, or stability of ribosomes in vivo (Noller and Woese 1981; Brimacombe et al. 1993; Ofengand and Fournier 1998; Decatur and Fournier 2002; $\mathrm{Xu}$ et al. 2008). Indeed, several rRNA modifications have been shown to be important for $30 \mathrm{~S}$ and $50 \mathrm{~S}$ assembly and ribosome functioning (Igarashi

Reprint requests to: Jaanus Remme, Institute of Molecular and Cell Biology, University of Tartu, Riia 23, 51010, Tartu, Estonia; e-mail: jremme@ebc.ee; fax: 3727420286.

Article published online ahead of print. Article and publication date are at http://www.rnajournal.org/cgi/doi/10.1261/rna.1186608. et al. 1981; Green and Noller 1996; Gustafsson and Persson 1998; Caldas et al. 2000), and a number of additional modifications provide advantages under particular conditions, such as conferring resistance against ribosometargeting antibiotics (Cundliffe 1989; Weisblum 1995; Mann et al. 2001; Toh et al. 2008). However, the possible functional roles of the vast majority of modified nucleosides in rRNA remain unknown. A useful tool for studying functional roles of modified nucleosides is to construct the bacterial strains carrying mutant genes for modification enzymes.

Thirty-six modified nucleosides are found at precisely determined locations of Escherichia coli K12 strain ribosomes, 11 in 16S rRNA and 25 in 23S rRNA. Pseudouridine is found at 11 positions, and various ribose and base methylations are found at 24 positions across ribosomal rRNA (Ofengand and Del Campo 2004; Andersen and Douthwaite 2006; 3D Ribosomal Modification Maps database, http://people.biochem.umass.edu/fournierlab/3dmod map/main.php). Uridine at position 1915 of $23 \mathrm{~S}$ rRNA is both isomerized to pseudouridine and methylated $\left(\mathrm{m}^{3} \Psi\right)$. 
In addition to pseudouridines and various methylated residues, one dihydrouridine (hU2449) and one 2-thiocytidine $\left(\mathrm{s}^{2} \mathrm{C} 2501\right)$ are found in 23S rRNA (Andersen et al. 2004; for review, see Ofengand and Del Campo 2004). Most of the genes encoding enzymes that modify rRNA have been identified. Identification of remaining genes encoding modification enzymes is a prerequisite for the use of genetic and biochemical tools for functional studies on the modified nucleosides.

Stem-loop 69 (H69) of E. coli 23S rRNA forms a distinct structure at the interface side of 50S subunit. H69 was the first RNA structural element that was identified as the RNA component of an intersubunit bridge (Mitchell et al. 1992), later named B2a (Gabashvili et al. 2000; Yusupov et al. 2001). In addition, $\mathrm{H} 69$ has been shown to participate in several ribosomal functions: H69 contacts A-site tRNA and translation factors; it is functioning during ribosome assembly and translation termination (Agrawal et al. 2004; Ali et al. 2006; Hirabayashi et al. 2006). The loop region of $\mathrm{H} 69$ contains several post-transcriptional modifications in all known large subunit RNAs (Ofengand et al. $2001)$. Pseudouridine $(\Psi)$ is found at positions 1911,1915 , and 1917, all of which are synthesized by pseudouridine synthase RluD (Huang et al. 1998; Raychaudhuri et al. 1998). Pseudouridines of $\mathrm{H} 69$ were shown to be important during translation termination (Ejby et al. 2007). In addition, the pseudouridine residue at position 1915 of $E$. coli $23 \mathrm{~S}$ rRNA is further methylated to form $\mathrm{m}^{3} \Psi$ (Fig. 1; Kowalak et al. 1996). The methyltransferase responsible for this modification was previously unknown, and the functional role of $\mathrm{m}^{3} \Psi$ modification has not been explored.

According to current knowledge, $\mathrm{m}^{3} \Psi 1915$ is the only methylated pseudouridine in bacterial RNAs (Rozenski et al. 1999; RNA Modification Database, http://library.med.utah. edu/RNAmods/), hence making the corresponding $\mathrm{m}^{3} \Psi$ methyltransferase a likely candidate for the only pseudouridine-specific methyltransferase in bacteria. In eukaryotes, $\mathrm{m}^{1} \Psi, \Psi \mathrm{m}$, and $\mathrm{m}^{1} \mathrm{acp}^{3} \Psi$ are found (Gray and Keddy 1974; Maden and Salim 1974; Saponara and Enger 1974; Maden et al. 1975; Brand et al. 1978). So far, no pseudouridinespecific methyltransferases have been described.
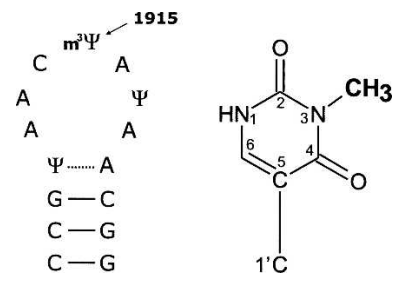

FIGURE 1. Secondary structure of E. coli 23S rRNA stem-loop 69 and the structural formula of $\mathrm{m}^{3} \Psi$. (Left) Stem-loop 69 contains three post-transcriptional modifications: two pseudouridines $(\Psi)$ and one 3-methylpseudouridine $\left(\mathrm{m}^{3} \Psi\right)$ located at position 1915 according to standard E. coli $23 \mathrm{~S}$ rRNA numeration. (Right, bold) The methyl group of the $\mathrm{m}^{3} \Psi$-modified base.
rRNA methyltransferases are enzymes that catalyze the transfer of a methyl group from $S$-adenosyl-L-methionine (SAM) to an acceptor residue in rRNA. Five classes of methyltransferases with structurally distinct folds have evolved convergently to bind the cofactor SAM and to perform the methyltransferase reaction (for review, see Ofengand and Del Campo 2004). There is no significant sequence conservation across all five methyltransferase classes. All known rRNA methyltransferases belong to class I or class IV. The genes corresponding to 16 out of the 24 rRNA methyltransferases predicted in E. coli have been identified (Andersen and Douthwaite 2006; Sergiev et al. 2007, 2008; Toh et al. 2008), and the majority of them belong to class I, characterized by the presence of a common, conserved Rossmann fold SAM binding domain (Schubert et al. 2003; for review, see Ofengand and Del Campo 2004). Much less conservation is noticed at the sequence level, where only a few conserved motifs are present, most of them being a part of the SAM binding region (Fauman et al. 1999). E. coli Gm2251 methyltransferase $\mathrm{RlmB}$ and $\mathrm{m}^{3} \mathrm{U} 1498$ methyltransferase RsmE are class IV methyltransferases and belong to the superfamily of proteins characterized by an intriguing $\alpha / \beta$ knot structure (Anantharaman et al. 2002; Forouhar et al. 2003; Schubert et al. 2003; Basturea et al. 2006; Basturea and Deutscher 2007). Recently, Tkaczuk et al. (2007) proposed to include the whole group of proteins with the $\alpha / \beta$ knot domain to the SPOUT superfamily of methyltransferases, regardless of the level of their functional characterization and the degree of sequence similarity to the SpoU and TrmD methyltransferases that historically gave the name to the SPOUT (SpoU-TrmD) family.

In this study, we report the identification of the methyltransferase gene (ybeA) responsible for the $\mathrm{m}^{3} \Psi 1915$ methylation in E. coli $23 \mathrm{~S}$ rRNA. The gene was identified by analysis of several putative RNA methyltransferase deletion strains and was confirmed by gene complementation, overexpression, and in vitro characterization of the purified YbeA protein. The enzyme has high specificity for Y1915 and does not methylate U1915. YbeA belongs to a SPOUT superfamily of methyltransferases and is the first pseudouridine-specific methyltransferase to be identified. In agreement with the accepted convention (Ofengand and Del Campo 2004; Andersen and Douthwaite 2006), we propose to rename the YbeA protein as RlmH (rRNA large subunit methyltransferase gene $\mathrm{H}$ ).

\section{RESULTS}

\section{Identification of the gene associated with the methylation of $\Psi 1915$ of $E$. coli $23 S$ rRNA}

The loop region of H69 in 23S rRNA contains three modified uridines. In addition to the methylated pseudouridine $\left(\mathrm{m}^{3} \Psi\right)$ at position 1915 , two additional pseudouridines are 
located at positions 1911 and 1917 (Fig. 1). Pseudouridines at positions 1911, 1915, and 1917 are synthesized by the RluD protein, while the methyltransferase responsible for $\mathrm{m}^{3} \Psi 1915$ synthesis is not identified yet (Kowalak et al. 1996; Raychaudhuri et al. 1998).

In order to identify the gene involved in methylation of $\Psi 1915$, for analysis we selected 11 genes predicted to encode RNA methyltransferases. Eleven putative RNA methyltransferase deletion strains (Fig. 2) were selected from the pool of E. coli clones ("KEIO" collection) containing single gene knockouts of all non-essential genes in the K-12 strain BW25113 background (Baba et al. 2006).

The methylation status of $\Psi 1915$ was initially screened by primer extension analysis of total rRNA isolated from 11 Keio collection knockout strains and the wild-type MG1655 strain (Fig. 2). Total ribosomal RNA was isolated from exponentially growing cells, and the methylation at position 1915 of $23 \mathrm{~S}$ rRNA was monitored. Methylation at the N3 position of the pseudouridine $\left(\mathrm{m}^{3} \Psi\right)$ perturbs Watson-Crick base-pairing and results in a strong reverse transcriptase stop.

In the case of E. coli MG1655 wild-type strain (Fig. 2, lane 12) and 10 out of 11 putative RNA methyltransferase knockout strains analyzed, the strong stop signal corresponding to the position 1915 of $23 \mathrm{~S}$ rRNA was observed (Fig. 2, lanes 1-8,10,11), indicating the presence of methylation. In contrast, no stop signal was detected in rRNA extracted from strain JW0631 (Fig. 2, lane 9), referring to the absence of methylation at position $\Psi 1915$ of 23 S rRNA. Strain JW0631 has the kanamycin-resistance cassette inserted into the putative RNA methyltransferase gene $y b e A$ and is hence renamed $\Delta y b e A$.

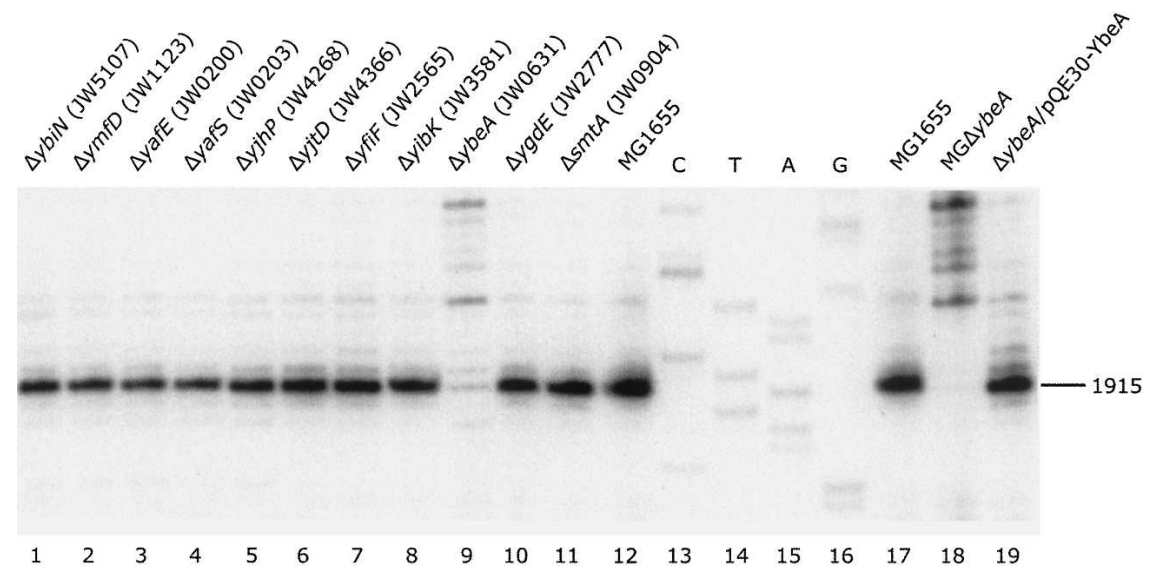

FIGURE 2. Analysis of 1915 region of E. coli $23 \mathrm{~S}$ rRNA by primer extension. rRNA was isolated from various putative RNA methyltransferase gene knockout strains from (lanes 1-11) the Keio collection, (lanes 12,17) E. coli wild-type MG1655 strain, (lane 18) the MG $\Delta y b e A$ strain, and (lane 19) the $\Delta y b e A / p Q E 30-y b e A$ strain. MG $\Delta y b e A$ is the $y b e A$ gene knockout in the MG1655 genetic background, and the $\Delta y b e A / p Q E 30-y b e A$ strain is the $\Delta y b e A$ strain transformed with a plasmid (pQE30-ybeA) expressing YbeA protein. A strong stop signal indicates the presence of methylation at position 1915. (Lanes 13-16) The sequence of the corresponding region of the E. coli $23 \mathrm{~S}$ rRNA gene.
A $y b e A$ gene knockout strain in the E. coli wild-type MG1655 background was constructed to eliminate the possibility that unknown second-site mutations in the JW0631 strain are responsible for the loss of the methylation at position 1915 of $23 \mathrm{~S}$ rRNA. The MG1655ybeA:: kan strain was generated by transducing E. coli strain MG1655 with P1 phage lysate derived from the phageinfected $\Delta$ ybeA strain (JW0631); the resulting knockout strain was named MG $\Delta$ ybeA. Deletion of the $y b e A$ gene did not have a detectable effect on the bacterial growth rate in rich medium at $37^{\circ} \mathrm{C}$ (data not shown). Primer extension analysis of rRNA demonstrated that the MG $\Delta y b e A$ strain, like the original JW0631 strain, lacked the methylation at position 1915 of $23 \mathrm{~S}$ rRNA (Fig. 2, lane 18), hence making the $y b e A$ gene a potential candidate for encoding $\mathrm{m}^{3} \Psi 1915$ methyltransferase.

\section{ybeA gene encodes $\mathrm{m}^{3} \Psi$ methyltransferase}

To test the possibility that the $y b e A$ gene encodes a protein responsible for the formation of $\mathrm{m}^{3} \Psi 1915$ of $23 \mathrm{~S}$ rRNA, gene complementation analysis was conducted. The ybeA gene was PCR-amplified using genomic DNA prepared from the E. coli MG1655 strain as a template, and cloned into a $\mathrm{pQE}-30$ expression vector, introducing an N-terminal His-tag. The recombinant YbeA protein was constitutively expressed in the $\Delta y b e A$ strain, and the methylation pattern of $\Psi 1915$ was monitored by primer extension analysis. Figure 2 shows a strong reverse transcriptase stop signal at position 1915 of $23 \mathrm{~S}$ rRNA when the $\Delta y b e A$ strain (JW0631) is transformed with the plasmid (pQE30/ybeA) expressing $\mathrm{N}$-terminally His-tagged YbeA protein (Fig. 2, lane 19). This finding suggests that the $y b e A$ gene is required for the introduction of the methyl group to $\Psi 1915$.

To verify the loss of $\mathrm{m}^{3} \Psi 1915$ methylation in the $y b e A$ deletion strain, RP-HPLC analysis of nucleosides was conducted. 70 S ribosomes were isolated from the wild-type MG1655 strain, $y b e A$ deletion strain $(\mathrm{MG} \Delta \mathrm{ybeA})$, and ybeA deletion strain complemented with a plasmid encoding YbeA protein (MG $\Delta y b e A / p Q E 30-y b e A)$. Phenol extracted RNA was used for oligonucleotide-directed RNase $\mathrm{H}$ excision of the $23 \mathrm{~S}$ rRNA fragments corresponding to nucleotides 1778-1921. Nucleoside composition of RNA fragments was analyzed by RP-HPLC using a modified multilinear gradient (Gehrke and Kuo 1989) on a Supelcosil LC-18-S HPLC column at $30^{\circ} \mathrm{C}$. The retention time of $\mathrm{m}^{3} \Psi$ under the conditions used is 11.73 min (Gehrke and Kuo 1989). 
HPLC chromatograms of the wild-type MG1655 strain revealed a nucleoside with the retention time $11.73 \mathrm{~min}$ (Fig. 3A), contrary to the nucleoside composition of the $y b e A$ knockout strain (MG $\Delta$ ybeA), where no signal was
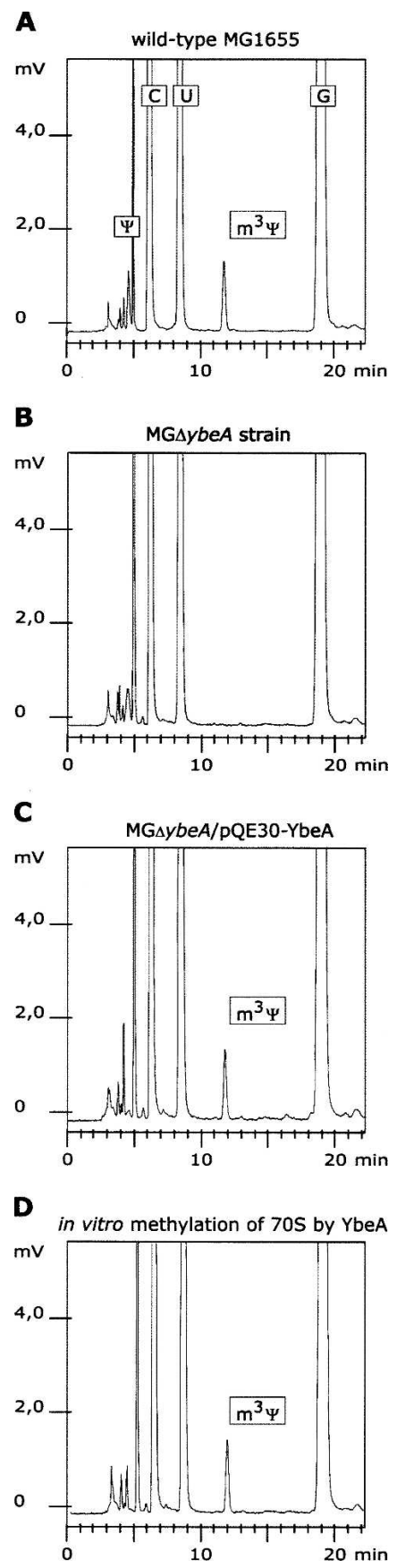

FIGURE 3. HPLC analysis of nucleoside composition of $23 \mathrm{~S}$ rRNA fragment corresponding to positions 1778-1921. The 23S rRNA fragment was isolated from $70 \mathrm{~S}$ ribosomes of E. coli strains $(A)$

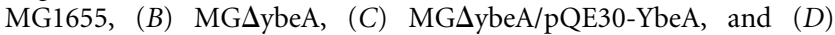
MG $\Delta y b e A$ strain ribosomes treated with YbeA in vitro. Peaks corresponding to three standard nucleosides $(\mathrm{C}, \mathrm{U}$, and $\mathrm{G})$ and two modified nucleosides, pseudouridine $(\Psi)$ and 3-methylpseudouridine $\left(\mathrm{m}^{3} \Psi\right)$, are indicated. detected in the corresponding region (Fig. 3B). When the ybeA deletion strain was complemented with a plasmid expressing recombinant YbeA protein, a strong signal (retention time $11.73 \mathrm{~min}$ ) corresponding to the $\mathrm{m}^{3} \Psi$ appeared on HPLC chromatograms (Fig. 3C). These data indicate that there is a causative relationship between the presence of the $y b e A$ gene and posttranscriptional methylation of $\Psi 1915$ in E. coli ribosomes, making YbeA protein the main candidate for $\mathrm{m}^{3} \Psi$ methyltransferase.

Table 1 represents a relative nucleoside composition of each RNA fragment compared to the wild-type reference probe. Interestingly, the absence of YbeA protein leads also to the reduced levels of $\mathrm{H} 69$ pseudouridines and $\mathrm{m}^{2} \mathrm{G} 1835$ in the $70 \mathrm{~S}$ ribosomes.

\section{YbeA protein has $\Psi 1915$-specific methyltransferase activity in vitro}

In order to test the functional properties of the $y b e A$ gene product, in vitro methylation assays were performed. Recombinant YbeA protein with N-terminal His-tag was purified by metal affinity chromatography. YbeA-dependent incorporation of $\left[{ }^{14} \mathrm{C}\right]$-methyl groups into ribosomes was monitored by TCA precipitation and scintillation counting. The purified YbeA protein was able to catalyze transfer of $\left[{ }^{14} \mathrm{C}\right]$-methyl groups from $\left[{ }^{14} \mathrm{C}\right]-S A M$ to the $70 \mathrm{~S}$ ribosomes isolated from the MG $\Delta$ ybeA strain but not to the ribosomes purified from the wild-type MG1655 strain (Fig. 4). About $70 \%-75 \%$ of the ribosomes isolated from the MG $\Delta$ ybeA strain were methylated giving an average of 0.7 methyl groups per ribosome (Fig. 4). Only 0.05 methyl groups were incorporated per $23 \mathrm{~S}$ rRNA when $50 \mathrm{~S}$ subunits were used as substrate (Fig. 4), indicating that YbeA is specific for fully assembled $70 \mathrm{~S}$ ribosomes. Specificity of the methylation reaction was verified by HPLC analysis. An aliquot of ribosomes from in vitro methylation assay was used for RNA fragment preparation and nucleoside composition determination. Ribosomal rRNA fragment isolated from $y b e A$ deletion strain MG $\Delta$ ybeA did not show any signal in the region corresponding to the $\mathrm{m}^{3} \Psi$ (retention time $11.73 \mathrm{~min}$ ) (Fig. 3B). Incubation of ribosomes with purified YbeA protein leads to appearance of strong signal at $11.73 \mathrm{~min}$ on the chromatogram (Fig. 3D). Approximately 0.65 methyl groups were incorporated per $70 \mathrm{~S}$ ribosome according to the chromatographic analysis, which is in good agreement with radioactivity incorporation data (Figs. 3, 4; Table 1).

To test whether the uridine or pseudouridine at position 1915 is a substrate for YbeA, 70S ribosomes from the $\Delta y b e A / \Delta$ rluD double knockout strain were isolated, and the efficiency of YbeA-directed methyl group incorporation in vitro was tested. The purified YbeA protein was unable to incorporate methyl groups into $70 \mathrm{~S}$ ribosomes isolated from the $\Delta$ ybeA $/ \Delta$ rluD double-knockout strain lacking 
TABLE 1. Quantification of nucleosides in 23S rRNA fragment 1778-1921

\begin{tabular}{lrrrrrrr}
\hline & $\mathrm{C}$ & $\mathrm{U}$ & $\mathrm{G}$ & $\mathrm{A}$ & $\Psi$ & $\mathrm{m}^{3} \Psi$ & $\mathrm{m}^{2} \mathrm{G}$ \\
\hline MG1655 & $100 \pm 0.9$ & $100 \pm 2.7$ & $100 \pm 2.5$ & $100 \pm 0.5$ & $100 \pm 2.7$ & $100 \pm 3.0$ & $100 \pm 3.7$ \\
MG $\Delta$ ybeA & $98 \pm 0.7$ & $103 \pm 0.9$ & $103 \pm 1.7$ & $97 \pm 1.3$ & $79 \pm 7.0$ & $0 \pm 0.2$ & $83 \pm 5.6$ \\
MG $\Delta$ ybeA/pQE30-YbeA & $100 \pm 1.0$ & $105 \pm 1.0$ & $105 \pm 1.0$ & $94 \pm 1.0$ & $64 \pm 1.0$ & $50 \pm 1.0$ & $64 \pm 1.0$ \\
MG $\Delta$ ybeA+YbeA $^{\text {a }}$ & $98 \pm 0.6$ & $103 \pm 0.4$ & $102 \pm 1.2$ & $98 \pm 1.2$ & $85 \pm 2.1$ & $63 \pm 1.6$ & $83 \pm 2.8$ \\
\hline
\end{tabular}

$70 \mathrm{~S}$ ribosomes were isolated, nucleosides of 23S rRNA fragment 1778-1921 were analyzed, and molar amounts of nucleosides were calculated as described in Materials and Methods. The relative molar amounts of nucleosides of three independent ribosome preparations are presented as relation to the $100 \%$ value of wild-type ribosomes.

${ }^{\mathrm{a}} 70 \mathrm{~S}$ ribosomes from MG $\Delta y b e A$ strain treated with purified YbeA protein as described in Materials and Methods.

both $y b e A$ and $r l u D$ genes (Fig. 4). RluD protein was shown to synthesize 1911, 1915, and 1917 pseudouridines in vitro using purified $70 \mathrm{~S}$ ribosomes as substrates, albeit at reduced efficiency as compared to the free $50 \mathrm{~S}$ subunits (Vaidyanathan et al. 2007). When $\Delta$ ybeA/ $\Delta$ rluD $70 S$ ribosomes were pre-incubated with purified RluD protein, they became substrates for YbeA-directed methylation (Fig. 4). These results show that the pseudouridine rather than uridine at position 1915 is the substrate for YbeA.

Taking together, we have shown that the $y b e A$ gene encodes a methyltransferase specific for methylation of $\Psi 1915$ of $23 S$ rRNA. Therefore, we propose the $y b e A$ gene to be renamed $r \operatorname{lmH}$ (ribosomal large subunit methyltransferase $\mathrm{H}$ ). The same result was found by our accompanying paper in this issue (Purta et al. 2008) using different methods.

\section{ybeA is a widely conserved gene}

YbeA belongs to the COG1576 cluster of SPOUT superfamily methyltransferases (Tkaczuk et al. 2007). Clusters of Orthologous Groups, also known as COGs, is a systematic grouping of gene families from completely sequenced genomes (Tatusov et al. 1997, 2003). Multiple sequence alignment of proteins from the COG1576 cluster of the SPOUT methyltransferase superfamily is shown in Figure 5. From each class of organisms with an annotated putative COG1576 member, one representative sequence was taken (31 sequences in total) and aligned with MUSCLE (Edgar 2004). Sequences for alignment were selected from COG (Tatusov et al. 2003) and RefSeq (Pruitt et al. 2007) databases as of March 2008.

Putative members of COG1576 were found in all three domains of life (Fig. 5). In eukaryotes, they are present in genomes of green plants (Viridiplantae). In Arabidopsis thaliana, the gene was annotated as a chloroplast protein. In archaea, the corresponding gene was found only in the phylum Euryarchaeota, and in bacteria in phyla Acidobacteria, Actinobacteria, Bacteroidetes, Cyanobacteria, Deinococcus-Thermus, Firmicutes, Fusobacteria, Lentisphaerae, Proteobacteria, Synergistetes, Thermotogae, and Verrucomicrobia (Fig. 5; Supplemental Fig. 1; Supplemental Table 1).
The taxonomy represented here is based on The NCBI Entrez Taxonomy Homepage (http://www.ncbi.nlm.nih. gov/sites/entrez?db=taxonomy) as of March 2008. Interestingly, while annotated the YbeA homolog is present in Mycoplasma pulmonis and Ureaplasma urealyticum, it is not present in Mycoplasma pneumoniae and Mycoplasma genitalium, and it is also missing from Rickettsiales among alpha-proteobacteria. The fact that parasites with small genomes have lost the $y b e A$ gene is interesting and probably indicates the secondary nature of such loss. Whether it has some biological importance remains to be seen.

The sequences of YbeA homologs are well conserved, especially the C-terminal part that is thought to contain the catalytic center. Six amino acids were universally conserved among the aligned sequences presented in Figure 5-G103, G107, H129, E138, R142, and Y152 (E. coli numbering). Of those six, G103 and G107 are in the predicted SAM binding motif (Anantharaman et al. 2002), and R142 is of particular interest as a potential catalytic amino acid (Fig. 5). Structurally equivalent arginine is also conserved in $\operatorname{TrmD}$ (R154 in E. coli) and is shown to be part of its catalytic center (Elkins et al. 2003). The role of highly conserved arginine in the catalytic center of another SPOUT

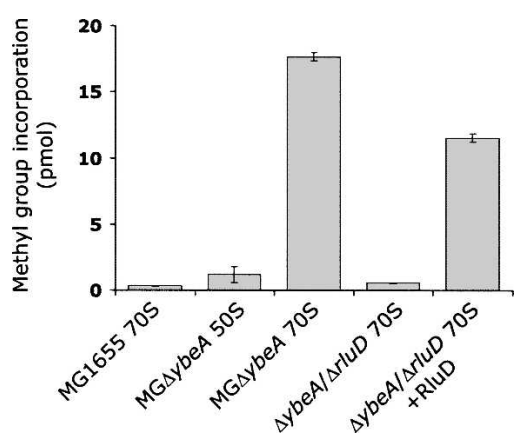

FIGURE 4. Methyltransferase activity of YbeA in vitro. $70 \mathrm{~S}$ ribosomes were isolated from E. coli wild-type MG1655, MGAybeA, and $\Delta y$ beA $/ \Delta$ rluD strains. Twenty-four picomoles of 70 S ribosomes or $50 \mathrm{~S}$ subunits was incubated with $100 \mu \mathrm{M}\left[{ }^{14} \mathrm{C}\right]-\mathrm{SAM}, 3 \mu \mathrm{g}$ of YbeA, and $1 \mu \mathrm{g}$ of RluD (if indicated). Incorporation of $\left[{ }^{14} \mathrm{C}\right]$-methyl groups into TCA insoluble material was determined. The data presented are the average of three experiments. 
$\operatorname{lns} 5$

Esccol.gi|16128619 Roslit.gi|163732522 Burdol.gi| 84362417 Camjej.gil15791514 Bdebac.gi| 42525168 Marfer.gi|114776729 Molirg.gi|88803363 Baccap.gi|154496020 Pedobacter_sp.gi|149279619 Synechococcus_sp.gi|116074639 Promar.gi|159903250 Bifden.gi|171741054 Rubxyl.gi|108804498 Themar.gi|15643607 Fusnuc.gil19703798 Deirad.gi|15805646 Akkmuc.gil166834251 Lenara.gi|149195686 Acibac.gi| 94967055 Solusi.gi|116624738 Synwol.gi|114567973 Bacsub.gi|16081075 Cloace.gi|15896772 Mycpul.gi|15828725 Metmar.gi|159906004 Methun.gi|88603833 Orysat.gi|115460408 Aratha.gil15238214

II Phypat.gil168060349 Chlrei.gi|159475549 Ostluc.gi|145344864

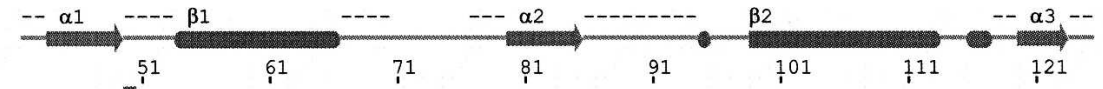

51 61 71

81

91

AA--AGKNRIVTLD

MRIHI IAV RLRAGPEKDIIDDYLTRFARSGRPLGLGPARIVEVEDRKNGG-_-_-_--MSNEAVLLRRAL-PDGALIAVLD MKLYIVAV LQVNIFCIQKSDE--FKTCSEKYSKLISK-----YATLKE INVFNKKIALAQNLNAIEAKKSYEEAFMP----YKKGYCIALD MKF I IYNLATAKE PWADEVSELYKKKISF------FIPFDIQSLKAKKSARED----ADFKRNEESELILKNI-NSDDYVVLFD MKLRIIVV RG RSRELAEFESR-FDQRLRP-----FADFQVVELPEGRAKQ------PVQRKQEEAKQIIT---HAGKGEILFD MKIKLIVI KT KHKSLLOLIEEYKNRLKH------YIKFEIETIPDI KNVKNLS---EIOOKEKEGTLILSKL-ONTDQLVLID LGIHVICV KLKEKFYTDASAEYAKRLGG-----YCKFQLTELPEERLPDNPSQAQIDAALRKEADAILQRL-PKGAAVTAMC

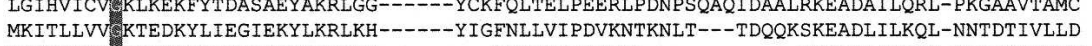

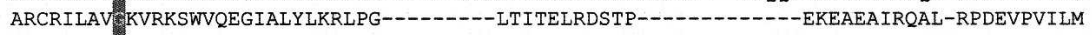

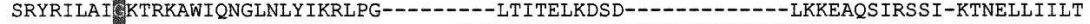
MKI TLITV KVKEKYLRDAIAEYSKRLGR-----YCKLDIVEVADEKTPEHAGEGLERQIKAKEGERIARYI-RDDAFVIALA RRATIVAV RIR-GWAAEGCEDYLRRLRR-----YFPVEVIEVAEADMNRLG----RGEALREEAGRLIRRL-PADAHVVALD

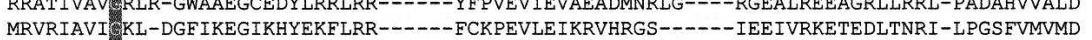
MNINI ICI KI KDKY INDGI AE F SKRMTS------FVSLNI IELKEYNKEDN-----INISIEKES LE ILKQISKSNSYNILLD MRLHLITVVE EPKLAYARSGWDEYEKRLRR-----YHKVQVSRV-----_---SGKTQQAESEAIIKA--AGKSPLILLD MQFLI LAA KPSLGYAKEGVELYLNRLRP-----FGKTELKLVRDGSS-IRVDFLVI KETKEKWIQTGIDKYLKRLKP------YANLTIKELPDQAVD-----_-----KRKDSKILQAV-SSRDLLILLD MKLRVVWI S KTKESAIQTLTGEYLKRISR-----YYVATEGLEIGSEEA-------LLKLKDRPG------RTAPVLVLMD

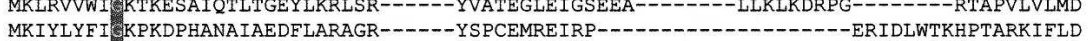

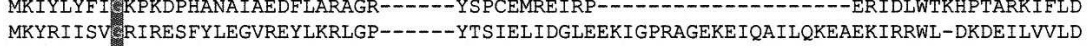
MNINIVTI I KLKEKYLKQGIEEYTKRLSA------YAKIDI IELPDEKAPENLSDQDMKIIKDKEGDRILSKI-SPDAHVIALA MNI TL ITVISKLKEKYLKDAVNEYAKRLQK-----YCKLNI IELQDEKTPEKASLKEEKLIKEKEGEKI LSSI-KDNSYVVSMD

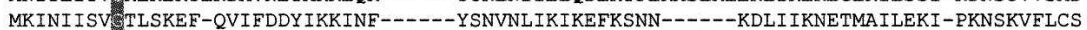
MNITIISV KIKEKYISGAI IEYSKRISR-----YSKLDI IEVADEKTRENPSDVEKSKLLEKEAERILKYL-KKDSFVITLE MNIT I I SVIKIKEKYLSGAIIEYSKRISR-----YSKLDI IEVADEKT RENP SDVEKSKLLEKEAERILKYL-KKDSFVITLE
VRIRIRAI KIKESFIRDAIADYAKRMCS----FCQVECIEYPEAPVPDTHPST-IEMACVSEGEKLCSGI-DSLDYVIILD MPMRVLTV KKRSRGAQLIVEEYKEKLGY------YCDIEDTLIKSNPKLTSD----VKVQVEAEDMAMMLQL-KPEDFVVVLD 11 LPIRVITV/KKRSEGVRLLVDEYKIKLKP------YCSEEDSLVRSNPRNAQD----VRAQVEDEEVAMMKLI-GSDDWVVVLD 111 MPMKLVTV 8 ALVQLITVSKENSKGATLFADELLEKVQR------YAPVQSINIKPNPRNSPD----PAVQRETEGEKVLKAL-DSRDLVVVLD 100 40 VPLVVVVV 112 Ins 5 Predicted SAM binding motif

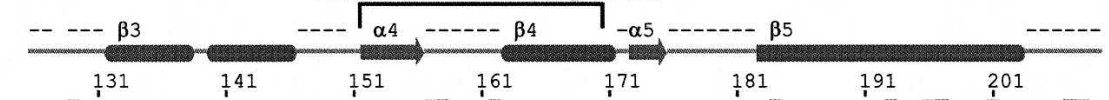

Esccol.gi|16128619
Roslit.gi|163732522
Burdol.gi|84362417
Camjej.gi||15791514
Bdebac.gi|42525168
Marfer.gi|114776729
Polirg.gi|88803363
Baccap.gi|154496020
Pedobacter_sp.gi|149279619
Synechococcus_sp.gi|116074639
Promar.gi|159903250
Bifden.gi|171741054
Rubxyl.gi|108804498
Themar.gi|15643607
Eusnuc.gi|19703798
Deirad.gi|15805646
Akkmuc.gi|166834251
Lenara.gi|149195686
Acibac.gi| 94967055
Solusi.gi|116624738
Synwol.gi|114567973
Bacsub.gi|16081075
Cloace.gi|15896772
Mycpul.gi|15828725
Metmar.gi|159906004
Methun.gi|88603833
Orysat.gi|115460408
Aratha.gi|15238214
Phypat.gi|168060349
Chlrei.gi|159475549
Ostluc.gi|145344864

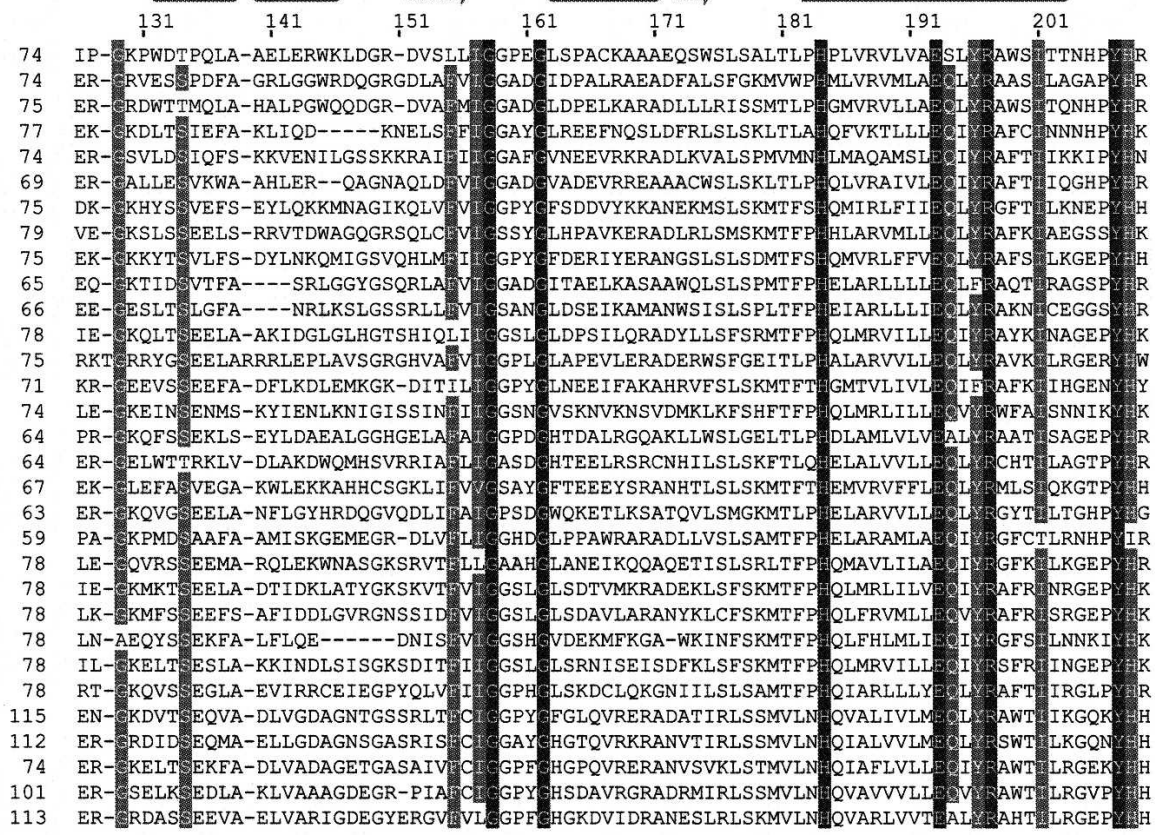

FIGURE 5. Sequence alignment of proteins belonging to the COG1576 cluster of SPOUT methyltransferases superfamily. The domains of organisms are indicated on the left as follows: (B) Bacteria; (A) Archaea; (E) Eukaryota. Each class of organisms is represented by one sequence, denoted by species name and NCBI gene identification (GI) number. Columns of residues are shaded according to the percent of identity: (dark gray) 100\% identity; (light gray) 90\% identity. Secondary structure elements derived from E. coli YbeA protein crystal structure (1NS5) are shown on top of the alignment, together with predicted SAM binding motif (Anantharaman et al. 2002). The alignment was performed using MUSCLE (Edgar 2004), and the figure was generated with Jalview (Clamp et al. 2004).

methyltransferase, TrmH, was recently shown (Watanabe et al. 2005). When the set of aligned sequences was widened to include a representative member from each family of organisms having a putative COG1576 member (95 sequences in total), the number of totally conserved amino acids was reduced to four-G107, E138, R142, and Y152 (Supplemental Fig. 1). As one of the four universally conserved amino acids was R142, it further 
supports the possible importance of R142 in YbeA catalytic activity.

\section{DISCUSSION}

An extensive bioinformatical analysis predicted the product of the $y b e A$ gene to be a member of the SPOUT superfamily of methyltransferases characterized by an intricate trefoilknot structure (Anantharaman et al. 2002; Tkaczuk et al. 2007). Several members of the SPOUT superfamily are confirmed to exhibit $\mathrm{Gm}$ (e.g., R $\mathrm{lmB}$ responsible for Gm2251 in 23S rRNA) and $\mathrm{m}^{1} \mathrm{G}$ (e.g., TrmD responsible for $\mathrm{m}^{1} \mathrm{G} 37$ in tRNA) methyltransferase activity in E. coli. RsmE protein, also a member of the SPOUT superfamily of methyltransferases according to recent classification (Tkaczuk et al. 2007), has an $\mathrm{m}^{3} \mathrm{U}$ methyltransferase activity (responsible for $\mathrm{m}^{3} \mathrm{U} 1498$ in 16S rRNA). Since corresponding enzymes for all of the $\mathrm{Gm}, \mathrm{m}^{1} \mathrm{G}$, and $\mathrm{m}^{3} \mathrm{U}$ modifications in E. coli rRNA have been accounted for, the remaining putative RNA methyltransferases of the SPOUT superfamily are speculated to synthesize modifications of different chemical nature (such as $\mathrm{m}^{3} \Psi$ ), or on different RNA substrates (Tkaczuk et al. 2007).

We have determined that the gene product of $y b e A$ is responsible for the post-transcriptional modification of $\Psi 1915$ to $\mathrm{m}^{3} \Psi$ in E. coli $23 \mathrm{~S}$ rRNA. Cells lacking the $y b e A$ gene carried non-methylated $\Psi$ at position 1915. Reintroduction of the $y b e A$ gene into the knockout strain restored the corresponding $\mathrm{m}^{3} \Psi$ methylation. Furthermore, purified YbeA protein was shown to synthesize $\mathrm{m}^{3} \Psi$ methylation in vitro using ribosomes purified from the ybeA knockout strain as a substrate. Notably, YbeA protein was not able to methylate ribosomes isolated from a $\Delta y b e A /$ $\Delta$ rluD double deletion strain. YbeA-directed methylation was activated by prior treatment of ribosomes with pseudouridine synthase RluD, suggesting that the substrate for YbeA is pseudouridine at position 1915. The identity of $\mathrm{m}^{3} \Psi$ was determined by RP-HPLC using $23 \mathrm{~S}$ rRNA fragment 1778-1921. It was important to use a fragment of $23 \mathrm{~S}$ rRNA that does not contain $\mathrm{m}^{5} \mathrm{C}$ (present at position 1962) due to the similar retention times during reversed phase chromatography. These results unambiguously establish YbeA as the methyltransferase that methylates $\Psi 1915$ in $E$. coli 23 S rRNA to $\mathrm{m}^{3} \Psi$.

Ribosome biogenesis is known to occur in a stepwise manner with some modifications synthesized on newly transcribed rRNA prior to its assembly into subunits (Liu et al. 2004). At the same time, synthesis of other modifications requires partially, or even fully assembled subunits (for review, see Ofengand and Del Campo 2004). RluD has been shown to be far more efficient in modifying H69 in structured 50S subunits, compared to free 23S rRNA; a low level of activity was seen even with $70 \mathrm{~S}$ ribosomes (Vaidyanathan et al. 2007). Analysis of the pseudouridylation pattern of $23 \mathrm{~S}$ rRNA of ribosome assembly precursor particles has shown that the pseudouridines in H69 are formed by RluD during the late assembly steps (Leppik et al. 2007). Given that synthesis of $\Psi 1915$ by RluD is likely to precede the methylation of the same position by YbeA, we propose that YbeA is also acting during the late step of ribosomes assembly. Furthermore, we show that both RluD and YbeA proteins are active on $70 S$ ribosomes. YbeA does not methylate the pseudouridine on free $50 \mathrm{~S}$ subunits. $70 \mathrm{~S}$ ribosomes are formed during the initiation step of protein synthesis. Purta et al. (2008) have found that docking of the YbeA crystal structure onto the 70S ribosomes suggests extensive contacts with both ribosome subunits, without any clash with the P-site tRNA (Purta et al. 2008). These data suggest that the last steps of ribosome assembly overlap with the first step of translation. We speculate that YbeA is involved in the quality control of ribosome biogenesis. Interestingly, deletion of the $y b e A$ gene has an effect on the modification level of nearby nucleosides. The absence of YbeA protein leads to slightly reduced amounts of all modified nucleosides in the 23S rRNA fragment 1778-1921 (Table 1). This points to possible interplay between modification enzymes RluD, RlmG, and $\mathrm{RlmH}$ during ribosome biogenesis.

The amino acid sequence of the YbeA protein has two C-terminal motifs that map to the SAM binding pocket, characteristic signatures of proteins belonging to the SPOUT superfamily. Proteins with highly significant similarity to YbeA exist in virtually all bacteria and are also found in genomes of green plants, as well as in the archaea phylum Euryarchaeota (Fig. 5). The YbeA homologs likely perform the same function in these organisms. The presence of the $\mathrm{m}^{3} \Psi$ modification in 23S rRNA was experimentally determined in E. coli (Kowalak et al. 1996). It is worth noting that Bacillus subtilis and Zea mays chloroplast ribosome large subunit rRNAs are very likely to contain the equivalent of $\mathrm{m}^{3} \Psi 1915$ as revealed by a strong reverse transcriptase stop (Ofengand et al. 1995). The extent of conservation of the $\mathrm{m}^{3} \Psi$ modification at the position equivalent to E. coli 1915 within the evolutionary domains is unknown.

Although both pseudouridines and methylated residues are widely distributed in $\mathrm{rRNA}, \mathrm{m}^{3} \Psi$ is the only derivative of pseudouridine thus far found in bacterial rRNA. Furthermore, to our knowledge, $\mathrm{m}^{3} \Psi$ in $23 \mathrm{~S}$ rRNA position 1915 (or equivalent) is the only example of methylated pseudouridine described in bacterial RNAs (including extensively modified tRNAs), making it in that sense "unique" (Rozenski et al. 1999; The RNA Modification Database, http://library.med.utah.edu/RNAmods/). The YbeA protein is hence a candidate for the only pseudouridine-specific methyltransferase in bacteria. Eukaryotic rRNAs also possess $\mathrm{m}^{1} \Psi$ (Brand et al. 1978), $\Psi \mathrm{m}$ (Gray and Keddy 1974; Maden and Salim 1974), and the hypermodified derivative $\mathrm{m}^{1} \mathrm{acp}^{3} \Psi$ (Saponara and Enger 1974; Maden et al. 1975). To our knowledge, no 
pseudouridine-specific methyltransferase has been described in eukaryotes.

The crystal structure of the YbeA protein has been determined (PDB 1NS5) (Benach et al. 2003), and like other SPOUT methyltransferases, it displays the $\alpha / \beta$ knot fold consisting of six-stranded parallel $\beta$-sheets flanked by $\alpha$-helices and an unusual C-terminal trefoil knot structure (Forouhar et al. 2003; Mallam and Jackson 2006). The deep trefoil knot in the YbeA backbone is formed by the threading of the last 35 residues (120-155) through a 45residue knotting loop (residues 74-119). YbeA crystallizes as an antiparallel homodimer, and the protein interface involves close-packing $\alpha 1$ and $\alpha 5$ from each monomer. Dimerization is consistent with other SPOUT methyltransferase crystal structures, although in some cases (e.g., RrmA and RsmE) the monomers are nearly perpendicular instead of being antiparallel. Dimerization is thought to be important for methyltransferase function as the knotted topology alone is not sufficient for maintaining the active conformation of the cofactor and substrate binding site (Nureki et al. 2004; Mallam and Jackson 2007a,b).

YbeA is composed solely of the core catalytic domain characteristic of SPOUT methyltransferases and lacks the extra N-terminal and C-terminal domains exhibited by many SPOUT methyltransferases (Benach et al. 2003; Tkaczuk et al. 2007). Comprehensive structural genomics data on the YbeA protein can be found in the accompanying paper by Purta et al. (2008).

The broad distribution of YbeA homologs among different species and the "uniqueness" of $\mathrm{m}^{3} \Psi$ modification imply that there must have been a compelling reason for the cells to evolve an enzyme catalyzing this modification. What could be the functional purpose of this methylation remains to be determined.

\section{MATERIALS AND METHODS}

\section{Strains and plasmids}

Single gene knockout mutants of E. coli strain BW25113 (Keio collection) were obtained from the Nara Institute of Science and Technology. In each of the 11 mutant strains studied (JW5107, JW1123, JW0200, JW0203, JW4268, JW4366, JW2565, JW3581, JW0631, JW2777, JW0904), one putative RNA methyltransferase gene is replaced with a kanamycin-resistance cassette (Baba et al. 2006).

The MG $\Delta$ ybeA (RE111) strain was generated by transducing the E. coli wild-type MG1655 strain (Blattner et al. 1997) with lysate derived from a P1 phage-infected $\Delta$ ybeA strain (JW0631, Keio collection), followed by selection of colonies based on acquired kanamycin resistance. Similarly, the $\Delta$ ybeA/ $\Delta$ rluD doubleknockout strain (RE112) was generated by transducing the E. coli $\Delta$ rluD (Leppik et al. 2007) strain with lysate derived from the P1 phage-infected $\Delta$ ybeA strain, followed by selection of colonies based on both kanamycin and chloramphenicol resistance. Constructed strains were confirmed for $y b e A$ and/or $r l u D$ deletion by PCR analysis.
For generation of the YbeA protein expression plasmid, the $y b e A$ gene was amplified by PCR from genomic DNA of the E. coli MG1655 strain. The N-terminal primer was 5' -CCATCGGATCC AAGCTGCAACTTGTCGCCG-3', which introduced a BamHI restriction site. The C-terminal primer was 5'-GGCTCAAGCTTT CACTCACGGTGATAAGGATGG-3', and introduced a HindIII restriction site. The purified PCR fragment was digested with appropriate restriction enzymes and cloned into pQE-30 expression vector (QIAGEN) between the BamHI and HindIII restriction sites. The constructed plasmid pQE30-ybeA contained the ybeA gene coding for a protein with an $\mathrm{N}$-terminal His-tag. Plasmid pQE60-rluD expressing RluD protein with a C-terminal His-tag was constructed as follows: The rluD gene was amplified by PCR from genomic DNA of the E. coli MG1655 strain. The Nterminal primer was $5^{\prime}$-GCCCATGGCACAACGAGTACAGCTC ACTGCA-3', which introduced an NcoI restriction site. The Cterminal primer was 5'-GCAGATCTTAACCAGTCCACTCCAT CCT-3' ${ }^{\prime}$, and introduced a BglII restriction site. The purified PCR fragment was digested with appropriate restriction enzymes and cloned into the pQE-60 expression vector (QIAGEN) between the NcoI and BglII restriction sites. Constructed plasmids were verified by sequencing.

For complementation analysis, the $\Delta y b e A$ strain was transformed with a pQE30-ybeA plasmid. Standard techniques were used for DNA manipulations, plasmid DNA isolation, and E. coli transformation (Sambrook et al. 1989).

\section{Preparation of ribosomes and rRNA}

Bacterial strains were grown at $37^{\circ} \mathrm{C}$ in $2 \mathrm{xYT}$ medium $(16 \mathrm{~g}$ of tryptone, $10 \mathrm{~g}$ of yeast extract, $5 \mathrm{~g}$ of $\mathrm{NaCl}$ per liter) supplemented with kanamycin $(50 \mu \mathrm{g} / \mathrm{mL})$, chloramphenicol $(20 \mu \mathrm{g} / \mathrm{mL})$, or ampicillin $(100 \mu \mathrm{g} / \mathrm{mL})$. Ribosomes were isolated from exponentially growing cells at $\mathrm{OD}_{600}=0.8 \mathrm{~S} 1.0$. Bacteria were collected by low-speed centrifugation and resuspended in buffer TKNMS (16\% sucrose $\left[\mathrm{w} / \mathrm{v}\right.$ ] in $6 \mathrm{mM} \mathrm{MgCl}_{2}, 60 \mathrm{mM} \mathrm{NH}_{4} \mathrm{Cl}, 60 \mathrm{mM} \mathrm{KCl}, 50$ $\mathrm{mM}$ Tris/ $\mathrm{HCl}$ at $\mathrm{pH} 8.0$, and $6 \mathrm{mM} \beta$-mercaptoethanol). Cells were lyzed by five freeze-thaw cycles in the presence of lysozyme (final concentration $0.5 \mu \mathrm{g} / \mathrm{mL}$ ) and DNase I (final concentration 50 units $/ \mathrm{mL}$ ). The S-30 lysate was prepared by centrifugation at $12,000 \mathrm{~g}$ for $30 \mathrm{~min}$ in an SS34 rotor (Sorvall), and the volume of the lysate was increased twofold with TKNM buffer $(12 \mathrm{mM}$ $\mathrm{MgCl}_{2}, 60 \mathrm{mM} \mathrm{NH}_{4} \mathrm{Cl}, 60 \mathrm{mM} \mathrm{KCl}, 20 \mathrm{mM}$ Tris/ $\mathrm{HCl}$ at $\mathrm{pH} 8.0$, and $6 \mathrm{mM} \beta$-mercaptoethanol). A total of $150 \mathrm{U}\left(\mathrm{OD}_{260}\right)$ of S-30 lysate was layered onto a $15 \%-30 \%(\mathrm{w} / \mathrm{w})$ sucrose gradient in TKNM buffer followed by centrifugation at 21,000 rpm for $17 \mathrm{~h}$ in a Beckman SW-28 rotor $\left(\omega^{2} t=2.96 \times 10^{11}\right)$. Gradients were analyzed with continuous monitoring of absorbance at $254 \mathrm{~nm}$. Ribosomal particles from gradient fractions were precipitated with 2.5 volumes of ice-cold ethanol and collected by centrifugation at $5000 \mathrm{rpm}$ for $30 \mathrm{~min}$ in an HS4 rotor (Sorvall). Ribosomal pellets were dissolved in TKNM buffer and used for RNA preparation. $70 \mathrm{~S}$ ribosomes were prepared as described above using sucrose gradient centrifugation in TKNM buffer. Gradient fractions containing $70 \mathrm{~S}$ ribosomes were collected, and ribosomal particles were sedimented by centrifugation at $39,000 \mathrm{rpm}$ for $20 \mathrm{~h}\left(\omega^{2} t=\right.$ $1.2 \times 10^{12}$ ) in a Beckman Ti50.2 rotor. 50S subunits were obtained by dissociating $70 \mathrm{~S}$ ribosomes. Ribosomal pellets were dissolved in TKNM buffer and stored at $-80^{\circ} \mathrm{C}$.

For primer extension analysis, the RNA was isolated from ribosome particles as described in Liiv et al. (2005). In the case of 
HPLC analysis, the rRNA was purified by extraction with phenol and chloroform followed by ethanol precipitation. rRNA was dissolved in water and stored at $-80^{\circ} \mathrm{C}$.

\section{Primer extension analysis}

Primer U1 (CAGCCTGGCCATCATTACGCC) complementary to positions 1972-1992 of E. coli 23S rRNA was annealed to rRNA extracted from $70 \mathrm{~S}$ ribosomes. The primer was extended by AMV reverse transcriptase (Seikagaku Corp.) according to the manufacturer's protocol using $\left[\alpha-{ }^{32} \mathrm{P}\right] \mathrm{dCTP}$ (Amersham Biosciences). Primer extension products were precipitated with ethanol; dissolved in loading buffer containing formamide, bromophenol blue, and xylene cyanol; and separated on a $7 \%$ polyacrylamide/ $8 \mathrm{M}$ urea denaturing gel. The gel was transferred to Whatman $3 \mathrm{MM}$ paper and vacuum-dried. Radioactivity was visualized by a Typhoon PhosphorImager (GE Healthcare).

Sequencing of E. coli $23 \mathrm{~S}$ rDNA was done using a U1 primer and CycleReader DNA Sequencing Kit (Fermentas Life Sciences).

\section{HPLC analysis}

\section{Preparation of $r R N A$ fragment}

A fragment of 23S rRNA corresponding to nucleotides 1778-1921 was excised by RNase $\mathrm{H}$ using oligonucleotides complementary to nucleotides 1760-1777 (primer C4: 5'-CAGTTGCAGCCAGC TGG-3') and 1922-1942 (primer U1 mini: 5'-TTTCGCTACCTT AGGACCG-3') of E. coli $23 \mathrm{~S}$ rRNA essentially as described by Douthwaite and Kirpekar (2007). In the denaturation step, 300 pmol of rRNA was mixed with a 10-fold molar excess of both oligodeoxynucleotides and heated for $3 \mathrm{~min}$ at $100^{\circ} \mathrm{C}$ in $270 \mu \mathrm{L}$ of $1 \mathrm{mM}$ EDTA. Denatured RNA probes were placed on ice, and $30 \mu \mathrm{L}$ of $10 \times$ buffer $(600 \mathrm{mM}$ HEPES at $\mathrm{pH} 7.0$ and $1.25 \mathrm{M} \mathrm{KCl})$ were added. In the hybridization step, the reactions were heated for $1 \mathrm{~min}$ at $90^{\circ} \mathrm{C}$ and cooled in a water bath over the period of 2 $\mathrm{h}$ to $45^{\circ} \mathrm{C}$. The resulting RNA-DNA hybrids were digested with 10 units of RNase $\mathrm{H}$ (Fermentas) in the presence of $8 \mathrm{mM} \mathrm{MgCl}_{2}$ and $1 \mathrm{mM}$ DTT for $30 \mathrm{~min}$ at $37^{\circ} \mathrm{C}$ to remove RNA/DNA heteroduplexes. Nuclease-treated RNA was phenol-extracted and recovered by ethanol precipitation, and the 143-nucleotide-long rRNA fragment was gel-purified using a 5\% LE TOP agarose gel. The RNA fragment was excised and extracted from the gel by overnight incubation in $450 \mu \mathrm{L}$ of $2 \mathrm{M} \mathrm{NH}_{4} \mathrm{OAc}\left(\mathrm{pH} \mathrm{6.0)}\right.$ ) at $4^{\circ} \mathrm{C}$. The RNA was precipitated with two volumes of 1:1 mixture of ethanol and isopropanol, collected by centrifugation, and dissolved in water.

\section{High performance liquid chromatography}

For HPLC analysis, 100-200 pmol of gel-purified RNA fragment were digested with nuclease P1 (MP Biochemicals) and bacterial alkaline phosphatase (Fermentas Life Sciences) according to the method of Gehrke and Kuo (1989). Nucleoside composition was determined by RP-HPLC on a Supelcosil LC-18-S HPLC column $(25 \mathrm{~cm} \times 4.6 \mathrm{~mm}, 5 \mu \mathrm{m})$ equipped with a pre-column $(4.6 \mathrm{~mm} \times$ $20 \mathrm{~mm}$ ) at $30^{\circ} \mathrm{C}$ on a SHIMADZU Prominence HPLC system.

The following buffers were used: buffer $\mathrm{A}\left(10 \mathrm{mM} \mathrm{NH}_{4} \mathrm{H}_{2} \mathrm{PO}_{4}\right.$, $2.5 \%$ methanol at $\mathrm{pH} 5.3)$, buffer $\mathrm{B}\left(10 \mathrm{mM} \mathrm{NH}_{4} \mathrm{H}_{2} \mathrm{PO}_{4}, 20 \%\right.$ methanol at $\mathrm{pH} 5.1)$, and buffer $\mathrm{C}\left(10 \mathrm{mM} \mathrm{NH}{ }_{4} \mathrm{H}_{2} \mathrm{PO}_{4}, 35 \%\right.$ acetonitrile at $\mathrm{pH}$ 4.9). RP-HPLC analysis was performed using the gradient conditions of Gehrke and Kuo (1989): flow rate 1.0
$\mathrm{mL} / \mathrm{min}$ held at $0 \% \mathrm{~B} 12 \mathrm{~min}$, to $10 \% \mathrm{~B}$ over $8 \mathrm{~min}$, to $25 \% \mathrm{~B}$ over $5 \mathrm{~min}$, to $60 \% \mathrm{~B}$ over $8 \mathrm{~min}$, to $64 \% \mathrm{~B}$ over $4 \mathrm{~min}$, to $100 \% \mathrm{~B}$ over $9 \mathrm{~min}, 0 \%-100 \% \mathrm{C}$ over $35 \mathrm{~min}$, held at $100 \% \mathrm{C}$ for $10 \mathrm{~min}$, and equilibration with $0 \% \mathrm{~B}$ for $30 \mathrm{~min}$. Nucleoside absorbance profiles were recorded at $260 \mathrm{~nm}$, and peak areas were integrated. For quantitative calculations, the following molar extinction coefficients (at $\mathrm{pH} 4.1$ ) were used: 13,100 for adenosine, 10,300 for guanosine, 6800 for cytidine, and 9000 for uridine (Holness and Atfield 1971).

\section{Purification of recombinant proteins}

Recombinant $\mathrm{N}$-terminal $\mathrm{His}_{6}$-tagged YbeA and RluD proteins were prepared from E. coli M15 cells (QIAGEN), harboring the pQE30-ybeA or pQE60-rluD plasmid. Cells were grown in $400 \mathrm{~mL}$ of $2 \mathrm{xYT}$ liquid media containing $50 \mu \mathrm{g} / \mathrm{mL}$ kanamycin and 100 $\mu \mathrm{g} / \mathrm{mL}$ ampicillin at $37^{\circ} \mathrm{C}$ to an $\mathrm{OD}_{600}$ of 0.5 . Isopropyl- $\beta-\mathrm{D}$ thiogalactopyranoside (IPTG) at $1 \mathrm{mM}$ was added, and incubation continued for $2 \mathrm{~h}$. Cells were harvested by low-speed centrifugation; resuspended in lysis buffer (50 mM NaH $\mathrm{PO}_{4}$, $1 \mathrm{M} \mathrm{NaCl}, 10 \%$ glycerol, $10 \mathrm{mM}$ imidazole at $\mathrm{pH} 7.0$ ); incubated on ice for $30 \mathrm{~min}$ with lysozyme (final concentration $1 \mathrm{mg} / \mathrm{mL}$ ) and DNase I (final concentration 40 units $/ \mathrm{mL}$ ); and were passed through a French pressure cell at 18,000 psi. Cell debris was removed by centrifugation at $16,000 \mathrm{rpm}$ for $30 \mathrm{~min}$ in a SS-34 Sorvall rotor. The recombinant YbeA protein was purified by nickel ion affinity chromatography on a Ni Sepharose 6 Fast Flow column (GE Healthcare Life Sciences) according to the manufacturer's instructions. Fractions containing YbeA protein were pooled; analyzed by SDS-PAGE; and dialyzed for $72 \mathrm{~h}$ against buffer: 10 $\mathrm{mM}$ Tris/ $\mathrm{HCl}$ at $\mathrm{pH}$ 7.6, $50 \mathrm{mM} \mathrm{NH}_{4} \mathrm{Cl}, 6 \mathrm{mM} \beta$-mercaptoethanol, and $1 \mathrm{mM}$ EDTA. Purified protein was concentrated with an Amicon Ultra Ultracel-3k filter, frozen in liquid nitrogen, and stored at $-80^{\circ} \mathrm{C}$ in dialysis buffer containing $50 \%$ glycerol.

\section{In vitro methylation assay}

Methyltransferase activity of YbeA protein in vitro was tested as follows: A reaction mixture $(75 \mu \mathrm{L})$ containing $24 \mathrm{pmol}$ of $70 \mathrm{~S}$ ribosomes or $50 \mathrm{~S}$ subunits, $3 \mu \mathrm{g}$ of purified YbeA protein, 100 $\mu \mathrm{M}\left[{ }^{14} \mathrm{C}\right]-S$-adenosyl-L-methionine (Amersham Pharmacia Biotech), and methylation buffer $(50 \mathrm{mM}$ Tris/ $\mathrm{HCl}$ at $\mathrm{pH} 8.0,100$ $\mathrm{mM} \mathrm{NH}_{4} \mathrm{Cl}, 10 \mathrm{mM} \mathrm{MgCl}_{2}$, and $1 \mathrm{mM} \mathrm{DTT}$ ) was incubated for $1 \mathrm{~h}$ at $37^{\circ} \mathrm{C}$. When indicated, pre-incubation of ribosomes with $1 \mu \mathrm{g}$ of purified RluD protein in the methylation buffer for $30 \mathrm{~min}$ at $37^{\circ} \mathrm{C}$ was performed. Reaction products were precipitated with $2 \mathrm{~mL}$ of ice-cold 5\% TCA. Samples were incubated for $30 \mathrm{~min}$ on ice prior to collection on glass fiber filters (Whatman). Filters were washed with $10 \mathrm{~mL}$ of $5 \%$ TCA, followed by $2 \mathrm{~mL}$ of $70 \%$ ethanol, and allowed to dry. Radioactivity was determined by scintillation counting using Optiphase HiSafe III scintillator (PerkinElmer).

Preparative methylation of $300 \mathrm{pmol}$ of $70 \mathrm{~S}$ ribosomes for HPLC analysis was performed in the same conditions.

\section{Multiple sequence alignment}

Multiple sequence alignment was done with MUSCLE (Edgar 2004). Sequences for alignment were selected from COG (Tatusov et al. 2003) and the RefSeq database (Pruitt et al. 2007) as of March 2008 so that each class of organisms having the annotated 
putative COG1576 member is represented by a single sequence. Taxonomy is based on The NCBI Entrez Taxonomy Homepage (http://www.ncbi.nlm.nih.gov/sites/entrez?db=taxonomy) as of March 2008.

\section{SUPPLEMENTAL DATA}

Supplemental material can be found at http://www.rnajournal.org.

\section{ACKNOWLEDGMENTS}

We thank Dr. H. Mori from the Nara Institute of Science and Technology, Japan for knockout strains; Professor S. Douthwaite (University of Southern Denmark) for useful discussions and comments on the manuscript; Dr. Ü. Maiväli and Dr. T. Tenson (both University of Tartu) for critically reading the manuscript; and M. Leppik for help and advice. The work was supported by Estonian Science Foundation Grants 7509 (to J.R.) and 7072 (to A.L.).

Received May 16, 2008; accepted July 9, 2008.

\section{REFERENCES}

Agrawal, R.K., Sharma, M.R., Kiel, M.C., Hirokawa, G., Booth, T.M., Spahn, C.M.T., Grassucci, R.A., Kaji, A., and Frank, J. 2004. Visualization of ribosome-recycling factor on the Escherichia coli 70 S ribosome: Functional implications. Proc. Natl. Acad. Sci. 101: 8900-8905.

Ali, I.K., Lancaster, L., Feinberg, J., Joseph, S., and Noller, H.F. 2006. Deletion of a conserved, central ribosomal intersubunit RNA bridge. Mol. Cell 23: 865-874.

Anantharaman, V., Koonin, E.V., and Aravid, L. 2002. SPOUT: A class of methyltransferases that includes spoU and trmD RNA methylase superfamilies and novel superfamilies of predicted prokaryotic RNA methyltransferases. J. Mol. Microbiol. Biotechnol. 4: 71-75.

Andersen, N.M. and Douthwaite, S. 2006. YebU is a m5C methyltransferase specific for $16 \mathrm{~S}$ rRNA nucleotide 1407. J. Mol. Biol. 359: 777-786.

Andersen, T.E., Porse, B.T., and Kirpekar, F. 2004. A novel partial modification at C2501 in Escherichia coli $23 \mathrm{~S}$ ribosomal RNA. RNA 10: 907-913.

Baba, T., Ara, T., Hasegawa, M., Takai, Y., Okumura, Y., Baba, M., Datsenko, K.A., Tomita, M., Wanner, B.L., and Mori, H. 2006. Construction of Escherichia coli K-12 in-frame, single-gene knockout mutants: The Keio collection. Methods Mol. Biol. 416: 171-181.

Basturea, G.N. and Deutscher, M.P. 2007. Substrate specificity and properties of the Escherichia coli 16S rRNA methyltransferase, RsmE. RNA 13: 1969-1976.

Basturea, G.N., Rudd, K.E., and Deutscher, M.P. 2006. Identification and characterization of RsmE, the founding member of a new RNA base methyltransferase family. RNA 12: 426-434.

Benach, J., Shen, J., Rost, B., Xiao, R., Acton, T., Montelione, G., and Hunt, J.F. 2003. X-Ray structure of Ybea from E. coli. Northeast Structural Genomics Research Consortium (NESG), PDB: 1NS5. European Bioinformatics Institute, European Molecular Biology Laboratory, Grenoble, France.

Blattner, F.R., Plunkett III, G., Bloch, C.A., Perna, N.T., Burland, V., Riley, M., Collado-Vides, J., Glasner, J.D., Rode, C.K., Mayhew, G.F., et al. 1997. The complete genome sequence of Escherichia coli K-12. Science 5: 1453-1474.

Brand, R.C., Klootwijk, J., Planta, R.J., and Maden, B.E.H. 1978. Biosynthesis of a hypermodified nucleotide in Saccharomyces carlsbergensis $17 \mathrm{~S}$ and HeLa-cell $18 \mathrm{~S}$ ribosomal ribonucleic acid. Biochem. J. 169: 71-77.

Brimacombe, R., Mitchell, P., Osswald, M., Stade, K., and Bochkariov, D. 1993. Clustering of modified nucleotides at the functional center of bacterial ribosomal RNA. FASEB J. 7: 161167.

Caldas, T., Binet, E., Bouloc, P., Costa, A., Desgres, J., and Richarme, G. 2000. The FtsJ/RrmJ heat shock protein of Escherichia coli is a $23 \mathrm{~S}$ ribosomal RNA methyltransferase. J. Biol. Chem. 275: 16414-16419.

Clamp, M., Cuff, J., Searle, S.M., and Barton, G.J. 2004. The Jalview Java alignment editor. Bioinformatics 20: 426-427.

Cundliffe, E. 1989. How antibiotic-producing organisms avoid suicide. Annu. Rev. Microbiol. 43: 207-233.

Cunningham, P.R., Richard, R.B., Weitzmann, C.J., Nurse, K., and Ofengand, J. 1991. The absence of modified nucleotides affects both in vitro assembly and in vitro function of the 30 S ribosomal subunit of Escherichia coli. Biochimie 73: 789-796.

Decatur, W.A. and Fournier, M.J. 2002. rRNA modifications and ribosome function. Trends Biochem. Sci. 27: 344-351.

Douthwaite, S. and Kirpekar, F. 2007. Identifying modifications in RNA by MALDI mass spectrometry. Methods Enzymol. 425: 1-20.

Edgar, R.C. 2004. MUSCLE: A multiple sequence alignment method with reduced time and space complexity. BMC Bioinformatics 5: 113.

Ejby, M., Sørensen, M.A., and Pedersen, S. 2007. Pseudouridylation of helix 69 of $23 \mathrm{~S}$ rRNA is necessary for an effective translation termination. Proc. Natl. Acad. Sci. 104: 19410-19415.

Elkins, P.A., Watts, J.M., Zalacain, M., van Thiel, A., Vitazka, P.R., Redlak, M., Andraos-Selim, C., Rastinejad, F., and Holmes, W.M. 2003. Insights into catalysis by a knotted TrmD tRNA methyltransferase. J. Mol. Biol. 333: 931-949.

Fauman, E.B., Blumenthal, R.M., and Cheng, X. 1999. Structure and evolution of AdoMet-dependent methyltransferases. In S-Adenosylmethionine-dependent methyltransferases: Structures and functions (eds. X. Cheng and R.M. Blumenthal), pp. 1-38. World Scientific, River Edge, NJ.

Forouhar, F., Shen, J., Xiao, R., Acton, T.B., Montelione, G.T., and Tong, L. 2003. Functional assignment based on structural analysis: Crystal structure of the yggJ protein (HI0303) of Haemophilus influenzae reveals an RNA methyltransferase with a deep trefoil knot. Proteins 53: 329-332.

Gabashvili, I.S., Agrawal, R.K., Spahn, C.M., Grassucci, R.A., Svergun, D.I., Frank, J., and Penczek, P. 2000. Solution structure of the E. coli $70 S$ ribosome at $11.5 \AA$ resolution. Cell 100: $537-549$.

Gehrke, C.W. and Kuo, K.C. 1989. Ribonucleoside analysis by reversed-phase high-performance liquid chromatography. J. Chromatogr. 471: 3-36.

Gray, M.W. and Keddy, G.M. 1974. Presence of $\mathrm{O}^{2{ }^{\prime}}$-methylpseudouridine in the $18 \mathrm{~S}+26 \mathrm{~S}$ ribosomal ribonucleates of wheat embryo. Biochemistry 13: 5453-5463.

Green, R. and Noller, H.F. 1996. In vitro complementatation analysis localizes $23 \mathrm{~S}$ posttranscriptional modifications that are required for Escherichia coli $50 \mathrm{~S}$ subunit assembly and function. RNA 2: 1011-1021.

Green, R. and Noller, H.F. 1999. Reconstitution of functional 50S ribosomes from in vitro transcripts of Bacillus stearothermophilus 23S rRNA. Biochemistry 38: 1772-1779.

Gustafsson, C. and Persson, B.C. 1998. Identification of the rrmA gene encoding the $23 \mathrm{~S}$ rRNA m1G745 methyltransferase in Escherichia coli and characterization of an m1G745-deficient mutant. $J$. Bacteriol. 180: 359-365.

Hirabayashi, N., Sato, N.S., and Suzuki, T. 2006. Conserved loop sequence of helix 69 in Escherichia coli $23 \mathrm{~S}$ rRNA is involved in A-site tRNA binding and translational fidelity. J. Biol. Chem. 281: 17203-17211.

Holness, N.J. and Atfield, G. 1971. Chromatographic separation of mononucleotides derived from transfer ribonucleic acids. Biochem. J. 121: 371-377. 
Huang, L., Ku, J., Pookanjanatavip, M., Gu, X., Wang, D., Greene, P.J., and Santi, D.V. 1998. Identification of two Escherichia coli pseudouridine synthases that show multisite specificity for $23 \mathrm{~S}$ RNA. Biochemistry 37: 15951-15957.

Igarashi, K., Kishida, K., Kashiwagi, K., Tatokoro, I., Kakegawa, T., and Hirose, S. 1981. Relationship between methylation of adenine near the $3^{\prime}$ end of 16-S ribosomal RNA and the activity of 30-S ribosomal subunits. Eur. J. Biochem. 113: 587-593.

Khaitovich, P., Tenson, T., Kloss, P., and Mankin, A.S. 1999. Reconstitution of functionally active Thermus aquaticus large ribosomal subunits with in vitro-transcribed rRNA. Biochemistry 38: $1780-1788$.

Kowalak, J.A., Bruenger, E., Hashizume, T., Peltier, J.M., Ofengand, J., and McCloskey, J.A. 1996. Structural characterization of $\mathrm{U}^{\star}-1915$ in domain IV from Escherichia coli $23 \mathrm{~S}$ ribosomal RNA as 3methylpseudouridine. Nucleic Acids Res. 24: 688-693.

Krzyzosiak, W., Denman, R., Nurse, K., Hellmann, W., Boublik, M., Gehrke, C.W., Agris, P.F., and Ofengand, J. 1987. In vitro synthesis of $16 \mathrm{~S}$ ribosomal RNA containing single base changes and assembly into a functional 30S ribosome. Biochemistry 26: 2353-2364.

Leppik, M., Peil, L., Kipper, K., Liiv, A., and Remme, J. 2007. Substrate specificity of the pseudouridine synthase RluD in Escherichia coli. FEBS J. 274: 5759-5766.

Liiv, A., Karitkina, D., Maiväli, U., and Remme, J. 2005. Analysis of the function of E. coli $23 \mathrm{~S}$ rRNA helix-loop 69 by mutagenesis. BMC Mol. Biol. 6: 18.

Liu, M., Novotny, G.W., and Douthwaite, S. 2004. Methylation of 23 S rRNA nucleotide G745 is a secondary function of the RlmAI methyltransferase. RNA 10: 1713-1720.

Maden, B.E.H. and Salim, M. 1974. The methylated nucleotide sequences in HELA cell ribosomal RNA and its precursors. $J$. Mol. Biol. 88: 133-164.

Maden, B.E.H., Forbes, J., de Jonge, P., and Klootwijk, J. 1975. The methylated nucleotide sequences in HELA cell ribosomal RNA and its precursors. FEBS Lett. 59: 60-63.

Mallam, A.L. and Jackson, S.E. 2006. Probing nature's knots: The folding pathway of a knotted homodimeric protein. J. Mol. Biol. 359: $1420-1436$.

Mallam, A.L. and Jackson, S.E. 2007a. A comparison of the folding of two knotted proteins: YbeA and YibK. J. Mol. Biol. 16: 650-665.

Mallam, A.L. and Jackson, S.E. 2007b. The dimerization of an $\alpha / \beta-$ knotted protein is essential for structure and function. Structure 15: $111-122$.

Mann, P.A., Xiong, L., Mankin, A.S., Chau, A.S., Mendrick, C.A., Najarian, D.J., Cramer, C.A., Loebenberg, D., Coates, E., Murgolo, N.J., et al. 2001. EmtA, a rRNA methyltransferase conferring high-level evernimicin resistance. Mol. Microbiol. 41: 1349-1356.

Mitchell, P., Osswald, M., and Brimacombe, R. 1992. Identification of intermolecular RNA cross-links at the subunit interface of the Escherichia coli ribosome. Biochemistry 31: 3004-3011.

Noller, H.F. and Woese, C.R. 1981. Secondary structure of $16 \mathrm{~S}$ ribosomal RNA. Science 212: 403-411.

Nureki, O., Watanabe, K., Fukai, S., Ishii, R., Endo, Y., Hori, H., and Yokoyama, S. 2004. Deep knot structure for construction of active site and cofactor binding site of tRNA modification enzyme. Structure 12: 593-602.

Ofengand, J. and Del Campo, M. 2004. EcoSal-Escherichia coli and Salmonella: Cellular and molecular biology (ed. R. Curtiss), Chap. 4.6.1. ASM Press, Washington, DC.

Ofengand, J. and Fournier, M.J. 1998. The pseudouridine residues of rRNA: Number, location, biosynthesis, and function. In Modification and editing of RNA (eds. H. Grosjean and R. Benne), pp. 229-253. ASM Press, Washington, DC.

Ofengand, J., Bakin, A., Wrzesinski, J., Nurse, K., and Lane, B.G. 1995. The pseudouridine residues of ribosomal RNA. Biochem. Cell Biol. 73: 915-924.
Ofengand, J., Malhotra, A., Remme, J., Gutgsell, N.S., Del Campo, M., Jean-Charles, S., Peil, L., and Kaya, Y. 2001. Pseudouridines and pseudouridine synthases of the ribosome. Cold Spring Harb. Symp. Quant. Biol. 66: 147-159.

Pruitt, K.D., Tatusova, T., and Maglott, D.R. 2007. NCBI Reference Sequences (RefSeq): A curated non-redundant sequence database of genomes, transcripts and proteins. Nucleic Acids Res. 35: D61D65.

Purta, E., Kaminska, K.H., Kasprzak, J.M., Buinicki, J.M., and Douthwaite, S. 2008. YbeA is the $\mathrm{m}^{3} \Psi$ methyltransferase $\mathrm{RlmH}$ that targets nucleotide 1915 in $23 \mathrm{~S}$ rRNA. RNA (this issue). doi: 10.1261/rna.1198108.

Raychaudhuri, S., Conrad, J., Hall, B.G., and Ofengand, J. 1998. A pseudouridine synthase required for the formation of two universally conserved pseudouridines in ribosomal RNA is essential for normal growth of Escherichia coli. RNA 4: 1407-1417.

Rozenski, J., Crain, P.F., and McCloskey, J.A. 1999. The RNA Modification Database: 1999 update. Nucleic Acids Res. 27: 196197.

Sambrook, J., Fritsch, E.F., and Maniatis, T. 1989. Molecular cloning: A laboratory manual, 2nd ed. Cold Spring Harbor Laboratory Press, Cold Spring Harbor, NY.

Saponara, A.G. and Enger, M.D. 1974. The isolation from ribonucleic acid of substituted uridines containing $\alpha$-aminobutyrate moieties derived from methionine. Biochim. Biophys. Acta 349: 61-77.

Schubert, H.L., Blumenthal, R.M., and Cheng, X. 2003. Many paths to methyltransfer: A chronicle of convergence. Trends Biochem. Sci. 28: 329-335.

Sergiev, P.V., Bogdanov, A.A., and Dontsova, O.A. 2007. Ribosomal RNA guanine-(N2)-methyltransferases and their targets. Nucleic Acids Res. 35: 2295-2301.

Sergiev, P.V., Serebryakova, M.V., Bogdanov, A.A., and Dontsova, O.A. 2008. The ybiN gene of Escherichia coli encodes adenine-N6 methyltransferase specific for modification of A1618 of $23 \mathrm{~S}$ ribosomal RNA, a methylated residue located close to the ribosomal exit tunnel. J. Mol. Biol. 375: 291-300.

Tatusov, R.L., Koonin, E.V., and Lipman, D.J. 1997. A genomic perspective on protein families. Science 278: 631-637.

Tatusov, R.L., Fedorova, N.D., Jackson, J.D., Jacobs, A.R., Kiryutin, B., Koonin, E.V., Krylov, D.M., Mazumder, R., Mekhedov, S.L., Nikolskaya, A.N., et al. 2003. The COG database: An updated version includes eukaryotes. BMC Bioinformatics 4: 41. doi: 10.1186/1471-2105-4-41.

Tkaczuk, K.L., Dunin-Horkawicz, S., Purta, E., and Bujnicki, J.M. 2007. Structural and evolutionary bioinformatics of the SPOUT superfamily of methyltransferases. BMC Bioinformatics 8: 73. doi: 10.1186/1471-2105-8-73.

Toh, S.M., Xiong, L., Bae, T., and Mankin, A.S. 2008. The methyltransferase $\mathrm{YfgB} / \mathrm{RlmN}$ is responsible for modification of adenosine 2503 in 23S rRNA. RNA 14: 98-106.

Vaidyanathan, P.P., Deutscher, M.P., and Malhotra, A. 2007. RluD, a highly conserved pseudouridine synthase, modifies $50 \mathrm{~S}$ subunits more specifically and efficiently than free $23 S$ rRNA. RNA 13: $1868-1876$.

Watanabe, K., Nureki, O., Fukai, S., Ishii, R., Okamoto, H., Yokoyama, S., Endo, Y., and Hori, H. 2005. Roles of conserved amino acid sequence motifs in the SpoU (TrmH) RNA methyltransferase family. J. Biol. Chem. 280: 10368-10377.

Weisblum, B. 1995. Erythromycin resistance by ribosome modification. Antimicrob. Agents Chemother. 39: 577-585.

Xu, Z., O’Farrell, H.C., Rife, J.P., and Culver, G.M. 2008. A conserved rRNA methyltransferase regulates ribosome biogenesis. Nat. Struct. Mol. Biol. 15: 534-536.

Yusupov, M.M., Yusupova, G.Z., Baucom, A., Lieberman, K., Earnest, T.N., Cate, J.H., and Noller, H.F. 2001. Crystal structure of the ribosome at $5.5 \AA$ A. Science 292: 883-896. 

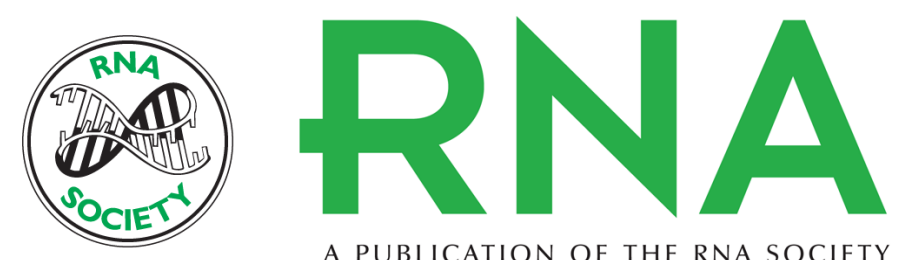

A PUBLICATION OF THE RNA SOCIETY

\section{Identification of pseudouridine methyltransferase in Escherichia coli}

Rya Ero, Lauri Peil, Aivar Liiv, et al.

RNA 2008 14: 2223-2233 originally published online August 28, 2008

Access the most recent version at doi:10.1261/rna.1186608

Supplemental

Material

References

\section{License}

Email Alerting

Service
http://rnajournal.cshlp.org/content/suppl/2008/08/29/rna.1186608.DC1

This article cites 65 articles, 21 of which can be accessed free at: http://rnajournal.cshlp.org/content/14/10/2223.full.html\#ref-list-1 